\title{
Leadership, violent conflict and reconciliation in Africa: the theological-sociocultural engagement of Luke's Gospel in social transformation ${ }^{1}$
}

\author{
Agbiji, Obaji M \\ University of South Africa \\ obajiagbiji@gmail.com \\ Etukumana, Godwin \\ Stellenbosch University \\ gaetukumana@yahoo.com
}

\begin{abstract}
This article considers anew the important role of leadership in a meliorating violent conflict and achieving reconciliation in African societies, using the Lukan Jesus' model of subversive leadership. The article critically engages Luke's narrative of Jesus' leadership style in achieving reconciliation in the context of violent conflict by using theological-sociocultural hermeneutical lenses. The Lukan Jesus, his leadership style and the manner in which he sought reconciliation in contexts of violent conflict offer African socio-political and religious leaders a model of effective leadership that could assist them in dealing with the social challenges Africa faces, such as poor leadership, violent conflicts and underdevelopment.
\end{abstract}

\section{Key words}

Leadership; reconciliation; violent conflict; theological-sociocultural approach; Lukan Jesus; Africa; social transformation patronizing

\section{Introduction}

The African continent has often been associated with poor leadership and violent conflicts (Gumede 2014:1; Shao 2001:24; Uvin 2003:116). There have

1 This material is based on work supported by the National Research Foundation of South Africa (NRF) under grant number 85113. Any opinion, findings and conclusions or recommendations expressed in this material are those of the authors and the NRF does not accept any liability in regard thereto. 
also been various attempts by political and religious leaders to achieve reconciliation in areas of the continent affected by violent conflict. The reconciliatory initiatives of African political and religious leaders include those of Léopold Senghor of Senegal, Julius Nyerere of Tanzania, Kenneth Kaunda of Zambia, Jomo Kenyatta of Kenya, and Nelson Mandela and Desmond Tutu of South Africa (Huyse 2003:34). Yet the Democratic Republic of the Congo, Rwanda, Burundi and South Africa have not recovered fully from the past atrocities of violent conflict. The rest of Africa has also been traumatised by waves of violent conflict, a costly plague that has distorted the continent's developmental path. Such waves of violence include coups, counter-coups, civil wars, mineral wars, political riots and religious violence that have negatively affected a number of African states (Kalu 2010a:271; cf. Tutu 2003:iii; Uvin 2003:116). Although Africa covers a broad context with varied socio-political and economic challenges, we base our discussion on an understanding of Africa as constituting "a specific cultural context" that allows for some degree of common identification amid great diversity. In spite of myriad subcultures, there are common denominators and cultural signifiers that underscore a shared identity among African nations and peoples (Kalu 2010b:4).

In this article, leadership is defined as the guidance of a group, party or political entity undertaken by an individual. The guidance that leaders offer could be by inspiration or charisma, through which they provide their followers with a vision that functions as a roadmap to new and unfamiliar terrains (Ruderman 1995:725-729; cf. Agbiji \& Swart 2013:222). Conflict can be defined as "the pursuit of contrary or seemingly incompatible interests between individuals, groups or countries" (DFID 2006:7). Violent conflict is the use of weapons or arms with an intention to intimidate, inflict injury or even cause death in the pursuit of such contrary or incompatible interests between individuals, or groups or countries. Reconciliation is "an over-arching process which includes the search for truth, justice, forgiveness, healing and so on” (Bloomfield 2003:12).

This study is guided by the theological-sociocultural hermeneutical approach of biblical interpretation (Berger 1967; Gager 1975; Theissen 1992). This methodology provides a lens that helps the reader to view the Bible as a sacred document that is meant to provide theological teachings for a given sociocultural context without undermining its social functions. Our interest 
in engaging in the issue of leadership, violent conflict and reconciliation in Africa lies in drawing from the rich resources that are contained in Luke's narrative as it relates to the role of leadership in resolving social conflicts and achieving reconciliation as portrayed by Jesus in the Gospel of Luke. Our discussion will then conclude with an invitation to African religious and socio-political leaders to be informed by the leadership style of Luke's Jesus in addressing the social challenges facing the African society such as poor leadership, violent conflict and underdevelopment.

\section{The concept of leadership in Greco-Roman society}

To understand the position of Luke in terms of leadership, his Gospel needs to be viewed in light of its immediate environment - Greco-Roman society. Leadership in this society manifested itself in different ways. Luke employs the sociocultural language of his time in order to emphasise his ideas on leadership to his community, using the language of patron/patronage and benefactor/beneficence to describe the standard leadership style of his time. The same language is used in Luke 4:18 where Jesus is seen as a benefactor or patron who has the power to liberate through the cancellation of debt (Danker 1982:395).

Patronage was the means by which Greco-Romans exercised leadership over their adherents (Marshall 2009:2). It is often argued about whether Luke's Gospel really reflects the patronage system that was practised during his time. Keith A. Reich (2011:33-34) is of the view that there is no doubt that Luke's material does indeed reflect the patronage system and that the use of the term in the Gospel shows that it was a dominant social practice during the time of Luke (22:25). The patronage system in the Greco-Roman world created a relationship between patron and client (Megbelayin 2001:192) and was a system that was of the utmost importance in the Roman Empire. This relationship was legally created through the process of Patrocinium (Ascough 2010:600) ${ }^{2}$ and was a mechanism used

2 Richards Ascough reviewed Jonathan Marshall's book: Jesus, Patrons, and Benefactors: Roman Palestine and the Gospel of Luke. According to Ascough, Marshall's opinion is that Luke admired Greco-Roman society, but there is no evidence in the Lukan narrative to show that Jesus ever criticised the Greco-Roman system. This opinion is in contrast to the views of Malina (1988:1-32) and Megbelayin (2001:192). 
by the leaders of the Roman Empire to wield power over their subjects. It produced a contract and platform that perpetuated dependency, while the patron decided on how to reward his beneficiaries or clients. The system was formalised at its highest level in the Imperial Cult.

Patrons as leaders (patronus, $\rceil \delta \varepsilon \mu \omega ́ v, \pi \alpha \tau \rho \omega ́ v$, and $\pi \alpha \tau \rho \omega ́ v \eta \varsigma)^{3}$ gave

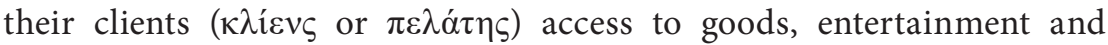
advancement. Anyone who received such benevolence accepted the obligation to publicly proclaim his/her gratitude for the generosity of his/ her benefactor, thereby promoting and enhancing the reputation of the patron. In this way, the client helped to enhance the reputation of the patron. The client also owed services to the patron and could be called on to perform certain tasks. Another figure that played an important role "in this network of patronage" is what Jeremy Boissevain (in deSilva 1996:93) calls a "broker". Boissevain argues: "persons who dispense first-order resources [e.g., land, jobs, and the like] may be called patrons. Those who dispense second-order resources [i.e., strategic contacts or access to patrons] are brokers". In the light of this view, deSilva (1996:93) affirms that the term "may seem modern, impersonal, and therefore inappropriate, but one must imagine the same personal relationship and duty between broker and client as between patron and client. Indeed, the "broker" is not a third entity sui generis, but rather a "client [or friend] to a patron and ... patron to a client".

The Emperor Augustus is the best-known patron of the time as head of the Roman Empire. In his Res Gestae Divi Augustus, Augustus lists the many honours that were given to him because of his role as emperor (Res. 35.1). According to Megbelayin (2001:194-195), Augustus himself mentioned about 23 titles and honours that were given to him by his people of which one of them was Pater Patriae (Res. 35.1); above all, Augustus was regarded as a god even when he was still alive. ${ }^{4}$

3 The term here is used without a gender bias. It represents both genders without emphasizing one above the other. The same applies to related terms such as "broker", "benefactor" and "client". The reason for this is that the system was widely practised and accepted by the society at the time (Levick 1985:141; Malina \& Rohrbaugh 1992:7475; Boissevain 1974:148; Danker 1982:436; Davis 1977:146).

4 Among these titles and honours are: Liberator of the People, Benefactor of Veterans, Benefactor of the People, Benefactor of the State, Benefactor of the Needy, Man of Piety, Restorer of the Temple and Public Work, Sponsor of Games and Shows, Peace Extender, Coloniser, Redeemer of the Standards, Friend of Kings, Man of Superb Distinction, 
Assessing the leadership styles in the immediate Lukan sociocultural environment provides grounds for Alicia Batten (2008:50) to believe that many patrons in the Roman Empire expected their clients to give them honour and respect in return for their service to them. Patronage was a highly sophisticated instrument that was designed to profit the patron. However, the relationship between patron and client could a times be confusing. The reason for this is that there was considerable hypocrisy in the ancient world. While patrons can refer to their clients as "friends", the true expression of their relationship as one between an inferior and a superior was only made clear when there was a need for the display of power on the part of the patron. This is demonstrated in the work of Decimus Iunius Iuvenalis (Juvenal, A.D. 55-120?). ${ }^{5}$ In Juvenal's fifth satire, which demonstrates patron-client friendship in a satirical way, Mark Morford (1977:236) remarks that two "friends" were in the client-patron relationship, which demonstrates the contrast between patron and client. This relationship is heightened beyond mere description by literary and rhetorical devices, and rather portrayed in particular allusions and associative imagery. The satire depicts patrons as using their clients to achieve their own selfish desires; in other words, the interests of the clients were not usually important to the patron. In assessing this particular satiric piece in the light of the leadership or patronage system in the Greco-Roman world, Batten (2008:50) further states that Juvenal describes a relationship between Virro (a wealthy man) and Trebius (a poor fellow). At the end of the satire the wealthy Virro, as was common in patronclient relationships humiliated the poor Trebius.

Another feature of patron-client relationship in the Greco-Roman world is the principle of reciprocity, which Malina (1986:101) defines as "the action and reaction of two sides or two distinct social interests." Malina argues that "the meaning embodied and realised in the vice versa reciprocity derives from the purpose of the interaction shared by one or both sides."

Father of His Country and many others. The number of these honours indicates that the Emperor Augustus was the most important patron of the Roman Empire (Blunt \& Moore 1967:18-37).

5 Juvenal's exact date of birth is a matter of debate among scholars. But the popular opinion is that he was born in about A.D. 55. His work is reckoned to be one of the best illustrations of the type of hypocrisy that existed in the client-patron relationship in the Greco-Roman world. For more information on this, see Batten (2008:50) and Merford (1977:228). 
The nature of the reciprocity witnessed in the relationship between a patron and client or the leader and the led was that which Malina (1986:101) calls the "pure self-interest" of the patron/leader, which was always to the disadvantage of the weaker party (the client/led). This sophisticated tool of exploitation was employed by the patron/leader to wield power over his/ her clients or subjects. In other words, his / her client saw the patron in this society as the source for the achievement of his/her desire. It is important to note that in ancient Greco-Roman society the reputation of a leader/ patron was proportional to the services rendered to him by his/her clients or subjects. The power to make decisions rested with the leader (patron), who was able to maintain this social relationship by exercising power over the people. R. P. Saller (1982:205) points out that exchange between the patron/leader and client was considered very important in facilitating their relationship, especially in political, legal and economic terms. This was a situation where "if a man's clientela was indicative of his current status, his potential for mobility depended on the effectiveness of patrons, whose wealth and political connections could be indispensable."

In terms of patronage/leadership in the Roman world, the emperor was regarded as nec peribus impar and also primus inter pares (basically, the central figure) in society. He was Pater Patriae 6 to the Empire. This gave him the power to dispense imperial beneficia to whomsoever he deemed fit to receive his patronage. This system demanded uncompromising devotion from all the peoples of the Principate (Empire), while, on the other hand, the emperor as Pater Patriae (father of his country) fulfilled his obligations to his people.

One of the duties of the emperor was to further the interests of the Empire in various ways. The web of patron-client relationships emanated from the emperor, who was the most important figure in society. The way in which

6 The Emperor Augustus said that he was privileged to be given this great honour by the Senate, the equestrian order and the people of Rome. The same attitude is confirmed by Cassius Dio in his writing when he said concerning this that "in addition to these remarkable privileges they named him father of his country, stamped this title on the coinage, voted to celebrate his birthday by public sacrifice, ordered that he should have a statue in the cities and in all the temples of Rome" (Res Gestae Divi Augusti, 35.1; Dio 44.4.4). This was one of the highest honours an emperor could receive. Horace was believed to have prayed that Caesar might defer his (Caesar's) death in order for him to continue to be honoured by the people of Rome with the title "father and chief citizen" (pater etqute princeps) (Blunt \& Moore 1967:80). 
the emperor dispensed his power endeared him to his people. One of the powers bestowed on the emperor was the ability to appoint any officer to any vacant position without the appointment being questioned. The notion of beneficio imperatoris made the decisions of the emperor binding on all within the Empire. Equally, his own duty was to serve the Empire as a great and unchallenged leader without rival. This required that every member of the Empire should ensure that he/she uncompromisingly fulfilled his/her obligations to the Emperor in return. According to Cicero (c.a. 44 A.D.), every patron/leader was expected to provide services to his/her clients. Cicero (in Saller 1982:61) advises people to ensure that the doing of their duty was commensurate with their obligations. ${ }^{7}$

Chow (1992:30-32) believes that the patron-client relationship was asymmetrical, reciprocal, particularistic, supra-legal, voluntary and vertical in nature. Politically, the client had the power to dispense honour (zópıs) to his/her patron to show his/her gratitude to the patron. The flourishing patronage system of Greco-Roman society was able to provide relative social peace, but at the expense of the masses (Reich 2011:33). It effectively provided the enabling environment for citizens to be exploited by their leaders in order to promote the latter's political identity.

\section{Jesus, the Greco-Roman concept of leadership and the Lukan theological-sociocultural narrative on leadership}

Jesus' views on leadership as portrayed by Luke's Gospel narrative were in stark contrast to those of Greco-Roman society. The utilisation of the language of patronage in Luke's immediate environment and its application in terms of governance or leadership provides insight into Luke's preference

7 Cicero further stated: "But in the performance of all these duties we shall have to consider what is most needful in each individual case and what each individual person can or cannot procure without our help. In this way we shall find that the claims of social relationship, in its various degrees, are not identical with the dictates of circumstances; for there are obligations that are due to one individual rather than to another: for example, one would sooner assist a neighbour in gathering his harvest than either a brother or a friend; but should it be a cases in court, one would defend a kinsman and a friend rather than a neighbour. Such questions as these must, therefore, be taken into consideration in every act of moral duty [and we must acquire the habit and keep it up], in order to become good calculators of duty, able by adding and subtracting to strike a balance correctly and find out just how much is due to each individual" (Cicero, 1.59). See also Saller (1982:16). 
for using the language of patron-client relationships to communicate to the community for which he was writing the quality of Jesus as an exceptional patron/leader of this new community (Danker 1982:324). According to

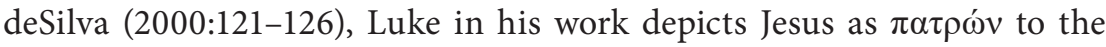
new community. DeSilva (2000:121-126) believes that Luke's use of the language of his time made it possible for his audience to understand him. Based on this understanding, God is the only true patron with the sole authority - like the Emperor - to dispense grace and favour to whomsoever he wills, while Jesus, on the other hand, acts as a broker between God and humanity (deSilva 2000:126-40). The duty of the Christian community was to respond to God's benevolence through Christ Jesus by remembering his acts of service to humanity. When Jesus implored the disciples to imitate his style of leadership in the Lukan text, it does not mean that Jesus expected $\chi \alpha$ ópı from his disciples, but rather their participation in his work for humanity. This obligation involved both identity and communion (Punt 2011:152) within the new community. This kind of leadership was to be rooted in the fear of God and service to humanity. The imitation of Lukan Jesus' leadership style implies providing for the poor at the margins of society, healing the broken-hearted, exercising forgiveness and working for the reconciliation of the broken world of humanity with God. John Gager (1975) emphasises the relationship between religion and society in the early Christian movement and its effect on our understanding of the New Testament. His argument is based on the interpretation formulated by Peter Berger in the 1960s. A theological-sociocultural reading of Luke in terms of leadership provides an interpretive scheme focused on a Godcentred leadership approach and its benefits to humanity.

As a result, James A. Sanders (2001:19) points out that the Lukan hermeneutical writing is theocentric, encompassing divine and human identities in a hermeneutical reading of a given text. Theissen (1992:36) believes that the contents of the New Testament did not originate in a vacuum but are informed by the sociocultural setting of the authors and their environment. The necessity of interpreting the biblical text in the context of a real human community and the function of the biblical text in terms of the transformation of human society prompted the abovementioned scholars to provide a sociocultural lens to assist the process of holistic biblical interpretation (Theissen 1992:60-61). 
The use of the theological-sociocultural method in studying Luke reveals the leadership challenges in various societies. Luke also believes that the operative ethos of his community has to be different from that of the "world" (O'Toole 1982:2). The theological-sociocultural hermeneutics of reading stresses the importance of social and cultural identity in terms of leadership and reconciliation. Luke's aim in his Gospel is that of identifying and positioning Jesus within the geopolitical, sociocultural, religious and economic contexts of his people, the Jews and the world in which he lived. In the same vein, it provides a basis for other societies to associate with that society and be informed by the timeless principles emanating from the teachings of Jesus.

\section{Lukan Jesus' leadership model in situations of violent conflict and reconciliation}

Luke's Gospel mentions cases where humanity was treated with disdain, but Jesus - as a leader par excellence - handled such situations quite differently. Scholars of Luke such as Halvor Moxnes (2001:192-194) and John G. Mason (2012:55-60) are of the opinion that Jesus' reading of the scroll of Isaiah in Luke 4:16-18 at the beginning of his ministry reveals the nature of his mission to humanity. The text also contains Jesus' leadership manifesto and portrays him as someone who saw himself as the messiah who would fulfil the Old Testament prophecies. J. R. Daniel Kirk (2011:143) believes that Jesus' aim was to fulfil two mandates in the history of the salvation of Israel: the Year of Jubilee and the restoration of Israel. Kirk (2011:143-144) further argues that in the ministry of Jesus, these two strands are interwoven. The hopes that Jesus fulfils are simply the "hopes of Israel that a Davidic king would rule the descendants of Abraham and this reign is one that literally brings sight to the blind and hearing to the deaf as well as a reversal of fortune for the socially marginalized and impoverished".

The gospel narrative is centred on mercy, love and compassion as inspiring factors that determined Jesus' subversive leadership style, which differed from that of his immediate society in order to address the needs of his time. Many patrons in Luke's time claimed to have compassion for their subjects, the patronage of Jesus was without any expectation of a reward of some 
kind from the people who benefited from it. His aim as patron was to serve humanity and liberate them from sin, poverty and disease (Luke 4:16-18; $5: 1-26 ; 22: 19-28)$.

\section{Lukan Jesus in situations of violent conflict}

Luke's Gospel provides us with many instances where Jesus was directly confronted with situations of violent conflict and the way in which he responded to these situations. These instances provide us with insight into the way in which Lukan Jesus articulated the language of reconciliation in situations of violent conflict, which he wanted his disciples to emulate and to teach the new community that he envisaged.

The Lukan narrative, or what might be considered a "Lukan peculiarity", especially the so-called Nazareth pericope, focuses on the way in which Jesus was an exemplary leader who avoided situations of violent conflict, as is evident in Luke 4:28-30:

When they heard this, all in the synagogue were filled with wrath. And they rose up and put him out of the city and led him to the brow of the hill on which their city was built, that they might throw him down headlong. But passing through the midst of them he went away.

The context of the narrative places the event soon after Jesus finished reading his manifesto to the people in Luke 4:16-18. Robert L. Brawley (1987:6-27) argues that the intention of Luke 4:16-18 was to identify Jesus' ministry with his Jewish people and to introduce him as a prophet with the Spirit of the Lord to fulfil the Old Testament scriptures. Jesus' identity as a Jew places his functions within his environment, which is an indication that every leader has a duty to address the needs of his/her immediate audience. The situation of violent conflict that arose soon after his declaration of his messianic visionary leadership to his people and the abrupt response from his people did not deter him from his vision (Carroll 2012:116). Patrick Spencer (2007:70) believes that this situation deprived Jesus of the opportunity to complete his speech. Luke's rhetorical presentation

8 "Lukan peculiarity" in this context refers to those texts that are peculiar only to Luke and not found in any of the other Gospels. The alternation of phrases in order to alter the initial meaning may also be regarded as Lukan peculiarity. 
of the story has its intertextual antecedent in the $\mathrm{LXX}^{9}$ reference to the theological-sociocultural norms that were in existence in Israel. It was a norm in Israel that a prophet was regarded as an exemplary leader with special power from God, a power to lead both the rich and poor in the Godward way. Jesus displayed his role here as a prophetic leader with a mission to liberate humanity. By implication, the Lukan narrative indicates that Jesus was not intimidated by the response of his immediate community, but, rather, was optimistic that he would achieve the purpose for which he was born (Tannehill 1996:93-94). The text depicts Jesus' use of non-violent resistance in his struggle for the liberation of humanity, and this in turn portrays him as a leader with compassion. He expected this attitude to be adopted by his followers, his immediate society and beyond.

Richard A. Burridge (2007) sees Luke 4:16-18 and the action of Jesus in it as one of the Lukan narratives that invite the Lukan community to imitate the lifestyle and attitude of Jesus as a patron and the leader of the new community. Martin W. Mittelstadt (2004:49) acknowledges that the incident later moulded the tenets of the early Christian community, since they were expected to act and behave as their master did. Luke in this narrative provides a springboard for future generations of Jesus' followers in order to reach the world with the prophetic leadership style learned from their master.

The case of the Samaritans' refusing Jesus entry to their community is peculiar to Luke's illustration of Jesus' attitude towards violent conflict as a good leader (Luke 9:51-56). Brawley (1987:27) argues that this was a lesson that Jesus wanted to teach his followers:

In a secondary sense, Luke's portrait of Jesus prefigures the careers of his followers. There is a qualitative distinction between who Jesus is and who they are. Nevertheless, the more they correspond to Jesus, the more their own relationship to God is guaranteed. Thus, they are legitimated as Spirit-filled leaders who authentically proclaim Jesus as the Spirit-anointed messiah and Mosaic prophet.

9 LXX stands for the Greek Version of the Old Testament popularly known as the Septuagint. 
J. M. Ford (1982:91) suggests that the disciples' question of whether to bring fire from heaven to consume the Samaritans (Luke 9:54), as appears in the ancient manuscript, becomes crucial in understanding Jesus' action in the text. The reason the disciples raised the question was because they saw the Samaritans as their enemies who needed to be annihilated and Jesus as a messianic figure who's purported mission, according to the Jews, was to destroy their enemies. Elijah had called down fire, and the fire had obeyed him; thus, Jesus in this context was expected to do the same thing as Elijah had done (2 Kings 1:9-16). But Jesus acted contrary in "an explicit and active denial of lex talionis (law of retaliation in Exodus 21:23-25) that the people expected of him" (Ford 2010:91).

In line with the theological-sociocultural interpretation of the Lukan text, it is apparent that the sociocultural interaction between the Samaritans and the Jews was one of racial and cultural prejudice. Josephus (Ant. 9:291) writes that the Samaritans were not trustworthy because they always denied their relationship to the Jews when the Jews were in difficulty and claimed their relationship with them when the Jews were prosperous. In terms of religious affinity, both Jews and Samaritans differed on a number of issues. The Jews, for example, worshipped in Jerusalem, while the Samaritans chose Mount Gerizim as their place of worship (1 Macc 1:10-44; Josephus, Ant. 12:257-264). Both the religious and sociocultural relationships between the Jews and the Samaritans were built on hatred and prejudice. However, Jesus' action in Luke was subversive of the expected theological-sociocultural norms of his people, including his disciples. Jesus acted as an exemplary leader whose duty was to bring healing to the broken relationship, thereby creating room for forgiveness and reconciliation.

Luke's account of Jesus during the conflict that ensued between his disciples and the soldiers that came to arrest him before his crucifixion is quite different from other synoptic writers (Matthew and Mark). It is only in Luke's account that Jesus healed the right ear of the servant of the chief priest that was cut off by one of the disciples (Luke 22:50). The reaction of Jesus in the last hours of his life in an extremely violent conflict situation in Luke 22:49-51 is thought-provoking. Frederick W. Danker (1982:421) makes an argument based on Jesus' reaction in the text: "it is difficult to escape the conclusion that Luke aims to assist his readers in understanding 
the total story of the crucifixion as an event at whose centre is a benefactor/ leader whose concern in his most perilous hours is the welfare of humanity". The cutting-off of one of the ears of the servant of the high priest and Jesus' response seems extraordinary compared to everyday human experience at moments of crisis. Thus, Jesus again illustrated to his disciples that a leader's primary concern is the welfare of both his followers and his enemies. Cassidy (2014:40-47) observes that the Lukan Jesus did not always subscribe to the use of non-violence and non-resistance, but on some occasions used these approaches to confront the political powers of his day. He, however, always did so in love (cf. Luke 17:3-4). In this account, Luke paints a picture of Jesus as an exemplary leader par excellence who responded with peace, healing, forgiveness and reconciliation to situations of violent conflict.

\section{Lukan Jesus and reconciliation}

Several actions in the Lukan text depict different nuances that were popular in the ancient Greco-Roman and Jewish culture with regard to reconciliation. Luke also associated leadership with reconciliation. Reconciliation in this context implies the ability of a leader to deal with the downtrodden by providing them with security and human dignity. It is apparent that in Luke's narrative the downtrodden and ostracised in society were given recognition through several of Jesus' actions that affected their lives. A case worth mentioning is that of the lepers in Luke 5:12-16 (cf. 17:12-19). Their meeting with Jesus altered the situation that they found themselves in and provided hope in their hopelessness.

Contrary to the Mosaic Code, Luke informs us that the attitude of Jesus towards the leper brought reconciliation into their lives (Morgan 2010:76). G. Campbell Morgan likens leprosy in Biblical texts to a moral malady that affects both the physical and the spiritual sides of those who suffer from it. Jesus effected reconciliation in the lives of the lepers socially, spiritually and culturally by curing their ailment. In terms of the requirements of the Old Testament, after being healed a leper was required to undergo a ritual purification. Luke uses the same process in his narration of the healing of the lepers by Jesus in Luke 5:12-16 and Luke 17:12-19. Sending them to show themselves to the priest according to the Law of Moses presupposes the action of reconciliation that the Old Testament authorises every person who had been certified as having been cleansed from leprosy to 
undertake. Steven A. Galipeau (2011:54) argues that "Jesus sought to help the leper become reconciled to his society as well as to heal the disease." Reconciliation is embedded in the narrative because the social, religious and cultural dimensions of these men were all restored. The cleansing $(\kappa \alpha \theta \alpha \rho \sigma \alpha 1)$ of the lepers was regarded as a form of total salvation, which entails salvation in all its various ramifications (Patella 2005:114). This has led Ford (2010:91) to conclude that Luke has an inclusive approach to ethnic and racial issues.

\section{Lukan Jesus' subversive leadership style and its imperative in social transformation}

It was mentioned earlier that the nature of the leadership style of the Lukan Jesus was subversive compared to that of the ancient Greco-Roman and Jewish theological-sociocultural context. According to Luke, Jesus issues a leadership imperative to his new community. This imperative is that leadership should respond to the theological and sociocultural needs of the community. The implementation of Lukan Jesus' leadership imperative was intentionally subversive of what pertained in Luke's immediate environment. In Luke 22:25 Luke uses the term "benefactor" to explain the nature of Greco-Roman leadership compared to the one expected of the new community. Luke 22:25 mentions that those who exercised authority

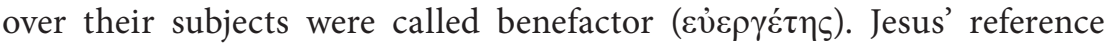

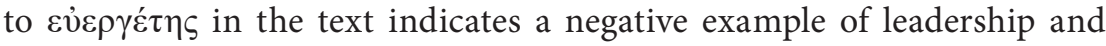
authority (Marshall 2009:286). It was common for Roman rulers to lord it over the people of the Roman Empire, as the Lukan text indicates. It was also common for a benefactor to use his/her patronage to exploit his/her clients (Marshall 2009:45). Malina (in Megbelayin 2001:193) acknowledges this and also points out that this system was exercised between people of unequal status, and thus kept the inferior person in his/her inferior social position. The system did not give the lesser partner any say in how the relationship would be conducted. The exploitation of a lesser partner was the aim of the patron-client relationship (Marshall 2009:46-47).

The Lukan Jesus had a different approach to how he wanted his new community and its leadership to function. In this context, Jesus saw himself as the supreme benefactor from God (Powell 1989:65-66) who humbled 
himself to the level of a servant to save humanity by restoring their dignity as human beings, irrespective of their social status. Luke's use of the term "benefactor" is congruent with the Hellenistic usage (Danker 1982:421422), but there is evidence of its subversiveness in the Lukan text. ${ }^{10}$

Luke's audience was advised to reject the leadership style of their immediate environment, the Greco-Roman society; i.e. the new Lukan community was to adopt a leadership style that was in direct contrast to the Greco-Roman style (Nelson 1994:86-87). The power of the text rests on the life of Jesus as an exemplary leader and culminates in the reversal of normal patronclient roles in the Last Supper. While Greco-Roman benefactors lorded it over their beneficiaries, for the Lukan Jesus, leaders were expected to be servants to their beneficiaries; in other words, the benefactor among the disciples has to take the position of a slave. This becomes clear during the Last Supper, when Jesus served the disciples instead of them serving him. This reversal of roles is expressed with a strong imperative in Luke 22:25, $\dot{v} \mu \varepsilon \tilde{\iota} \zeta \delta \grave{\varepsilon}$ ov่ $\chi$ oú $\tau \omega \varsigma$ (But not so with you, RSV). The rendition of this in the New Living Translation forcefully expresses its imperative nature and its function to the Lukan community: "But among you it will be different." This instruction given to the disciples (Nelson 1994:155) indicates that their attitude towards leadership within the new community must be in contrast to the one practised in their immediate environment, i.e. Greco-Roman society (Marshall 2009:192-200). The function of such an imperative was to create a selfless leadership style in the Lukan Jesus community that in turn would communicate peace, love and reconciliation to humanity. This imperative became manifest in the Lukan community in Acts, where the apostles rendered selfless services to the human community. ${ }^{11}$

10 Scholars are not unanimous regarding the actual meaning of Luke's use of the term "benefactor" in this context: Danker, Powell, Crook, etc. are of opinion that the term is use in tandem with the usage in Greco-Roman society. But Marshall argues differently as to the understanding of the usage in the Greek and Roman society. His argument is that Luke uses the word in Greek in the context of Roman patronage and not in the Greek sense. He further argues that Greek benefactors did not accept any rewards from their beneficiaries (Marshall 2009:32-52).

11 Luke provides basic information on how the new community exercised the principle of leadership that was taught to them by their master, Jesus. The first example is the demonstration that both the physical and spiritual aspects of humanity are important to God when the disciples heal the sick and provide for the poor during their ministry (Acts $3: 2 ; 6: 1-7$ ). 
The final teaching of Jesus on mercy, compassion, selflessness and love as some of the basic qualities of a leader in Luke are expressed by the sacrifice of his life for the sins of humankind (Luke 22:19-20; 23:34). This view stands in contrast to the views of some scholars (Powell 1989:70-71; cf. Scaer 2005:90-134; Neyrey 2007:157) who see no soteriological significance in the death of Jesus. However, other scholars argue that when the Lukan narrative of Jesus' passion is read as a whole and in light of the Lukan peculiarity, Luke's intention regarding the death of Jesus and its salvific significance will not be in doubt (Denaux 2010:276-300). Recently, scholars like Stanley Porter have shown that reading Luke's Gospel theologically alongside an understanding of the historical and cultural context of the time shows that the death of Jesus in Luke was salvific and has enormous redemptive benefits for humanity. This same belief is also found in Paul's view of Jesus' death (Porter 2011:160-165).

The Lukan narrative of Jesus' leadership style reaches its climax in Jesus' willingness to die on the Cross. The discussion between the two criminals crucified with him sums up the reason for his going to the Cross (Luke 23:39-43). Luke's audience understood implicitly the Lukan narrative that Jesus was a leader without any selfish desires whose blood was a means of atonement for the sins of his people (Luke 22:19-20). The portrait of the Lukan Jesus is that of a selfless servant-leader who leads his community to victory without demanding any reward from them.

\section{The Lukan Jesus, leadership, violent conflict, reconciliation and social challenges in Africa}

One may ask what role Luke's view on leadership could play in Africa, especially in terms of leadership, violent conflict and reconciliation. African biblical exegetes such as Lobe-Mkole (2010:117-121) have argued that good leadership could provide lasting solutions to the problems that African countries are facing and African societies could experience rapid social transformation if the Lukan narrative of Jesus' leadership style can be emulated by Africa's religious and socio-political leaders. Many lessons can be derived from Luke's Gospel that could benefit the continent, which is plagued by poor leadership and ravaged by war, poverty and hunger (Harrison 2011:369). Samuel M. Muriithi (1997:51) has argued that with its rich extensive resources yet to be explored, Africa is potentially the 
richest continent in the world. However, Africa's riches do not seem to play a positive role in its development because compared with other continents, it is the least developed and the poorest, coupled with a huge debt burden.

Tony Blair (2001) in his speech to the Labour Party while prime minister of Great Britain, said that after surveying the problems facing Africa that Africa in the 1960s and 1970s was far better off than Africa in the new millennium. He further argued that Africa was far better off than East Asia in the 1960s and 1970s, but today Africa is in a far worse state than East Asia. As a result, Blair concluded that: "The state of Africa is a scar on the conscience of the world." Both arguments express the sorry state of the African continent. Unfortunately, Muriithi in his book African Development Dilemma: The Big Debate blames the state of Africa on the Western world but fails to look inward in order to offer a solution to the African crisis. This in essence worsens the situation, since Africa has the tendency to project the cause of its problems on others. Blair, on his part, did not attempt to solve the problems by pointing out clearly where they lie. We posit that the Western world aids and abets violent conflicts in Africa. However, there is hardly any society that is void of conflict and indeed violent conflict. What makes a huge difference is the manner in which conflicts are managed from becoming violent conflicts; and violent conflicts can be managed and resolved before they get into the way of socio-economic and political progress (Mtingele 2016). This is where the role of leadership is invaluable.

It is the view of many scholars that Africa is the way it is because of its bad governance and leadership. The same notion is held by Monday N. Kogbara (2010:2) who argues that the prevalence of violent conflicts in Africa is as a result of leaders mishandling conflict. ${ }^{12}$ Robert I. Rotberg (2004 para.12) blames bad leadership as the major cause of Africa's problem when he argues that African leaders use power as an end in itself, rather than for the public good; they are indifferent to the progress of their citizens (although anxious to receive their adulation); they are unswayed by reason and employ poisonous social or racial ideologies; and they are hypocrites,

12 Monday N. Kogbara (2010) deals with different methodologies of dealing with conflict of which one of them is what he calls community-conflict education programme in which he proposes that every leader in Africa has to participate in this process so as to be able to mediate conflict and govern people with equity. 
always shifting blame for their countries' distress. Under the stewardship of these leaders, infrastructure in many African countries has fallen into disrepair, currencies have depreciated, and real prices have inflated dramatically, while job availability, health care, education standards, and life expectancy have declined. Ordinary life has become beleaguered: general security has deteriorated, crime and corruption have increased, much-needed public funds have flowed into hidden bank accounts, and officially, sanctioned ethnic discrimination - sometimes resulting in civil war - has become prevalent.

This study recognises that the leadership system in Africa is largely to blame for the poverty, disease, war, and religious and ethnic conflicts in the continent after many years of independence (Owoye \& Bissessar 2014:227228). So far, African leaders have not emulated the leadership style of Jesus portrayed in Luke's narrative. The Lukan Jesus' religious-sociocultural ethos of leadership and its positive impact could reposition African leaders in terms of their attitudes to their religious and sociocultural domains (Bolden \& Kirk 2009:5).

A number of research projects have been conducted in Africa with the intention of resolving the leadership challenges facing Africa. Some of these studies and the solutions they have advocated include Global Leadership and Organisational Behaviour Effectiveness, or GLOBE (Hoppe 2007:1-5; Hoppe \& Eckert 2014:1-3), the Hofstede Technique (Bolden \& Kirk 2009:4) and the Delphi Technique (Senaji et al. 2014:5-16). Some of these have been effective in identifying the quality of leadership that African people crave based on their cultural settings. All the techniques used during the research are similar in their methods and utilisation of data, e.g. the use of interviews of individuals or groups.

The findings and data generated by these organisations proved that many people in Africa are craving for selfless leaders with integrity, vision and the ability to respond to conflict situations. The GLOBE report on the leadership culture in some countries, including Africa, used a 7-point scale to show what people desire most and least in their leaders (Hoppe \& Eckert 2014:4). The figures given in the table below are percentages showing the extent to which people want a particular quality in their leaders, based on the 7-point scale: 


\begin{tabular}{|l|l|l|l|}
\hline Integrity & 6.07 & Inspirational & 6.07 \\
\hline Visionary & 6.02 & Performance-oriented & 6.02 \\
\hline Team integrator & 5.88 & Decisive & 5.80 \\
\hline Administrative competence & 5.76 & Diplomatic & 5.49 \\
\hline Collaborative team orientation & 5.46 & Self-sacrificial & 5.0 \\
\hline Modesty & 4.98 & Humane & 4.78 \\
\hline Status conscious & 4.34 & Conflict inducer & 3.97 \\
\hline Procedural & 3.87 & Autonomous & 3.85 \\
\hline Non-participative & 2.66 & Autocratic & 2.65 \\
\hline Self-centred & 2.17 & & \\
\hline
\end{tabular}

The findings show that people expect their leaders to have high peoplecentred attributes and less selfish tendencies (Hoppe \& Eckert 2014:4). The same attributes are required to change the state of Africa in both the public and private domains.

The results of the abovementioned study reveal the desire of the masses for good governance, whether in the public, private or ecclesiastical spaces. Good leadership is what the African continent and the world at large need. Monday N. Kogbara (2010:6-10) insists that leadership, irrespective of level of education has to be built on compassion. This leadership (in both the private and public spaces) has to be built on selflessness, non-violence, forgiveness, peace and reconciliation. The Lukan narrative leadership style becomes important here because it includes all the attributes of good leadership mentioned above, together with the fear of God, compassion, mercy, love and care for humanity. The following insights can therefore be drawn from Luke's narrative:

1. Lukan Jesus' attitude towards the people he had contact with indicates the nature of the leadership he provided to his community. For African leaders to tackle the impending crisis on the continent there has to be a conscious change in their approach to leadership from a totalitarian and uncaring system to a more proactive way of handling conflicts through non-violent resistance, as applied by the Lukan Jesus.

2. The Lukan Jesus' emphasis on compassion, love, mercy and peace indicates basic qualities that every good leader should possess. African leaders have to buy into a system of leadership that is people- 
centred instead of a selfish and self-centred leadership style that has been the major cause of conflict in the continent.

3. There is an urgent need for the adoption of the Lukan subversive approach to leadership, which could transform the leadership system in Africa. If adopted by African leaders, the subversive leadership style practised by Jesus would help to reverse the egregious trend in leadership that has been the underlying factor in the continent's regression. The subversive leadership style in this context implies leaders doing things that are beneficial to people and society, motivated by love, mercy and compassion, and not self-centred desires and greed.

4. There is a need for past leaders to be imitated. This study emphasises that African leaders should imitate the Lukan Jesus if this continent is to experience a change from poor leadership to good governance. In support of this view, Roberts Rotberg (2004) believes that present and future leaders in Africa should emulate past leaders who have left indelible marks through their selfless service to God and humanity. He believes that there must be a conscious imitating of past African leaders such as Sir Seretse Khama of Botswana, Sir Seewoosagur Ramgoolam of Mauritius, Kwame Nkrumah of Ghana, Nnamdi Azikiwe of Nigeria and Nelson Mandela of South Africa, who gave their all to the service of Africa and its people. Imitation of his leadership style was an imperative that the Lukan Jesus stressed to his disciples in Luke 22:19.

5. Luke proposes servant-leadership as an alternative to the "selfaggrandising" leadership style that has been the norm in leadership systems in Africa and elsewhere. A servant-leader has the advantage over the self-aggrandising leader because he is able to condescend to the level of the people, know their needs, and address them without causing conflict.

\section{Conclusion}

This article has considered the place of leadership in the context of violent conflict and reconciliation using the model of Jesus in the Gospel of Luke. Several examples in Luke show how Jesus responded to situations 
of violent conflict. A typical example of this is that of the Samaritans in Luke 9:52-56. The article engaged the theological-sociocultural approach of hermeneutics to study Lukan Jesus' leadership style. The model enabled the study to read Luke's narrative on Jesus in terms of his reaction to violent conflict and his mediation of forgiveness and reconciliation. The study looked at the place of leadership in the Lukan environment and it was discovered that Luke utilised various contrasts to express the meaning of leadership in his context. One such contrast was the patron-patronage system as one of the leadership styles found in the ancient Greco-Roman society, compared with that of Jesus in the Gospel of Luke. It was found that the method of the Lukan Jesus was in direct contrast to the practice of the Greco-Roman world, since it was compassionate, selfless, non-violent, peaceful, forgiving and reconciliatory. According to Luke, the disciples of Jesus were expected to emulate this style of leadership and to teach humankind to do the same.

Similar to Greco-Roman society, African society is facing social challenges such as poor leadership, violent conflict and the need for reconciliation. The problem of leadership is at the core of Africa's social challenges. Many African leaders are self-centred in their approach to governance and this approach to leadership leads to violent conflicts that ultimately stall development. Suggestions have therefore been offered based on Lukan Jesus' leadership style as a normative alternative to poor leadership in Africa. It is believed that the Lukan leadership style, if emulated, would contribute positively to leadership development in Africa and could curtail violent conflicts; foster peace, forgiveness and reconciliation; and further pave the way for enduring social transformation.

\section{References}

Ascough, R. S. 2010. "Jesus, Patrons, and Benefactors: Roman Palestine and the Gospel of Luke (Reviewed)." Catholic Biblical Quarterly, 72(3), January: 599-601.

Agbiji, O. M. \& Swart, I. 2013. "Historical Sources of Christian Religious Leadership Ideology: Implications and Challenges for Social Transformation in Post-military Nigeria." Studia Historiae Ecclesiasticae, 39(1): 221-246. 
Batten, A. 2008. "The Patron-Client Institution, God in the Letter of James: Patron or Benefactor." In Neyrey, J. H. \& Stewart, E. (Eds). The Social World of the New Testament: Insight and Models. Peabody: Hendrickson, 47-61.

Berger, Peter L. 1969. The Sacred Canopy: Elements of a Sociological Theory of Religion. Garden City: Anchor Books.

Blair, T. 2001. https://keeptonyblairforpm.wordpress.com/2001-blairs-leaders-speech-toconference/. Accessed 2/26/2015.

Bloomfield, D. 2003. "Reconciliation: An Introduction." In Bloomfield, D., Barnes, T. \& Huyse, L. (Eds). Reconciliation after Violent Conflict: A Handbook. Stockholm: International Institute for Democracy and Electoral Assistance, 1-18.

Boissevain, J. 1974. Friends of Friends. Oxford: Oxford University Press.

Bolden, R. \& Kirk, P. 2009. "African Leadership: Surfacing New Understandings through Leadership Development." International Journal of Cross Cultural Management, 9(1): 69-86.

Brawley, R. L. 1987. Luke-Acts and the Jews: Conflict, Apology, and Conciliation. Atlanta: Scholar Press.

Brunt, P. A. \& Moore, J. M. (Eds). 1967. Res Gestae Divi Augusti: The Achievement of the Divine Augustus. Oxford: Oxford University Press.

Burridge, R. A. 2007. Imitating Jesus: An Inclusive Approach to New Testament Ethics. Grand Rapids: Eerdmans.

Carroll, J. T. 2012. Luke: A Commentary. Louisville: Westminster John Knox Press.

Cassidy, R. J. 2015. Jesus, Politics, and Society: A Study of Luke's Gospel. Eugene: Wipf \& Stock.

Chow, J. K. 1992. Patronage and Power: A Study of Social Networks in Corinth. London: Sheffield Academic Press.

Cicero. De Officiis. http://www.constitution.org/rom/de_officiis.htm (2012, January 22). 
Danker, F. W. 1982. Benefactor: Epigrapic Study of a Graeco-Roman and New Testament Semantic Field. St. Louis: Clayton.

Davis, John. 1977. The People of the Mediterranean: An Essay in Comparative Social Anthropology. London: Routledge \& Kegan Paul.

Denaux, A. 2010. Studies in the Gospel of Luke: Structure, Language and Theology. Berlin: Lit Verlag.

DeSilva D. A. 2000. Honor, Patronage, Kinship and Purity: Unlocking New Testament Culture. Downers Grove: InterVarsity Press.

DeSilva, D. A. 1996. "Exchanging Favour for Wrath: Apostasy in Hebrews and Patron Client Relationships.” Journal for Biblical Literature, 115(1): 91-116.

DFID (Department for International Development). 2006. Preventing Violent Conflict. http://reliefweb.int/sites/reliefweb.int/files/resources/94F32632765 OB3D3C12572DD004BD0CF-dfid-conflictprevention-may07.pdf. Accessed 22/6/2015.

Ford, J. M. 1982. “Reconciliation and Forgiveness in Luke’s Gospel.” In Cassidy, R. J. \& Scharper, P. J. (Eds). Political Issues in Luke-Acts. Maryknoll: Orbis Books.

Ford, J. M. 2010. My Enemy Is My Guest: Jesus and Violence in Luke. Eugene: Wipf \& Stock.

Gager, J. G. 1975. Kingdom and Community: The Social World of Early Christianity. Englewood Cliffs: Prentice-Hall.

Galipeau, S. A. 2011. Transforming Body and Soul: Therapeutic Wisdom in the Gospel Healing Stories. Carmel: Fisher King Press.

Gumede, V. 2014, “Thought Leadership, Thought Liberation, and Critical Consciousness for Africa's Development and a Just World.” Unpublished inaugural lecture, University of South Africa, Pretoria, South Africa, 19 March.

Hoppe, M. H. \& Eckert, R. 2014. The Leader, Effectiveness and Culture: The GLOBE Study. http://www.ccl.org/leadership/pdf/assessments/GlobeStudy.pdf. Accessed 1/3/2015. 
Hoppe, M. H. 2007. Culture and Leader Effectiveness: The GLOBE Study. http://www.inspireimagineinnovate.com/pdf/globesummary-by-michael-h-hoppe.pdf.

Huyse, L. 2003. “Zimbabwe: Why Reconciliation Failed.” In Bloomfield, D., Barnes, T. \& Huyse, L. (Eds). Reconciliation after Violent Conflict: A Handbook. Stockholm: International Institute for Democracy and Electoral Assistance, 34-39; 116-121.

Josephus, F. 1999. The New Complete Works of Josephus. Whist on, W. (Trans.). Grand Rapids: Kregel.

Kalu, O. U. 2010a. "Global Theology and the Violent Face of Religion." In Kalu, W., Wariboko, N. \& Falola, T. (Eds). Religions in Africa: Conflicts, Politics and Social Ethics. The Collected Essays of Ogbu Uke Kalu, Vol. 3, 269-290. Trenton: Africa World Press.

Kalu, O. U. 2010b. “African Protestant Theology.” In Kalu, W., Wariboko, N. \& Falola, T. (Eds). Religions in Africa: Conflicts, Politics and Social Ethics. The Collected Essays of Ogbu Uke Kalu, Vol. 3, 3-10. Trenton: Africa World Press.

Kirk, J. R. D. 2011. Jesus Have I Loved, but Paul? A Narrative Approach to the Problem of Pauline Christianity. Grand Rapids: Baker Academic Books.

Levick, B. 1985. The Government of the Roman Empire: A Sourcebook. London: Croom Helm.

Lewin, H. (Ed.). 1987. A Community of Clowns: Testimonies of People in the Rural Mission. Geneva: WCC Publications.

Lobe-Mkole, J. 2010. “The New Testament and Intercultural Exegesis in Africa.” In Foster, P. (Ed.). New Testament Studies 1. Los Angeles: Sage, 113-132.

Malina, B. \& Rohrbaugh, R. 1992. Social Science Commentary on the Synoptic Gospels. Minneapolis: Fortress.

Malina, B. 1986. Christian Origins and Cultural Anthropology: Practical Models for Biblical Interpretation. Louisville: John Knox Press. 
Malina, B. J. 1988. "Patron and Client: The Analogy behind Synoptic Patron and Client: The Analogy behind Synoptic Theology." Forum, 4(1): 2-32.

Marshall, J. 2009. Jesus, Patrons, and Benefactors: Roman Palestine and the Gospel of Luke. Tübingen: Mohr Siebeck.

Mason, J. G. 2012. Luke: An Unexpected God. Sydney South: Aquila Press.

Moxnes, H. 2001. "Kingdom Takes Place: Transformations of Place and Power in the Kingdom of God in the Gospel of Luke." In Pilch, J. J. (Ed.). Social Scientific Models for Interpreting the Bible: Essays by the Context Group in Honor of Bruce J. Malina. Leiden: Brill, 176-209.

Megbelayin, I. O. J. 2001. A Socio-rhetorical Analysis of the Lucan Narrative of the Last Supper. PhD thesis, St. Paul University, Ottawa. http://web.ebscohost.com.ez.sun.ac.za (2011, November 22).

Mittelstadt, M. W. 2004. The Spirit and Suffering in Luke-Acts:

Implications for a Pentecostal Pneumatology. London: T. \& T. Clark.

Morford, M. 1977. Classical Mythology. New York: McKay.

Morgan, G. C. 2010. The Gospel According to Luke. Eugene: Wipf \& Stock.

Mtingele, Mkunga H. P. 2016. Leadership and Conflict in African

Churches: The Anglican Experience. New York: Peter Lang.

Muriithi, S. M. 1997. African Development Dilemma: The Big Debate. Lanham: American University Press.

Nelson, P. K. 1994. Leadership and Discipleship: A Study of Luke 22:24-30. Atlanta: Scholars Press.

Neyrey, J. H. 2007. The Passion According to Luke: A Redaction Study of Luke's Soteriology. Eugene: Wipf \& Stock.

Kogbara, M.N. 2010. African leadership and conflict resolution: a guide to quality education for schools in Africa. Bloomington: Xlibris Corporation.

O’Toole, R. F. 1982. "Luke's Position on Politics and Society in LukeActs.” In Cassidy, R. J. \& Scharper, P. J. (Eds). Political Issues in LukeActs. Maryknoll: Orbis Book, 1-17. 
Owoye, O. \& Bissessar, N. 2014. "Corruption in African Countries: A Symptom of Leadership and Institutional Failure." In Mudacumura, G. M. \& Morçöl, G. (Eds). Challenges to Democratic Governance in Developing Countries. Cham: Springer, 227-246.

Patella, M. 2005. The Gospel According to Luke. Collegeville: Order of Saint Benedict.

Porter, S. E. 2011. “Luke: Companion or Disciple of Paul?” In Willitts, J. \& Bird, M. F. (Eds). Paul and the Gospels: Christologies, Conflicts and Convergences. London: T. \& T. Clark, 146-168.

Powell, M. A. 1989. What Are They Saying about Luke? Mahwah: Paulist Press.

Punt, J. 2011. "Identity, Memory and Scriptural Warrant: Arguing Paul's Case." Journal of Early Christian History, 1(2), November: 152-173.

Reich, K. A. 2011. Figuring Jesus: The Power of Rhetorical Figures of Speech in the Gospel of Luke. Leiden: Brill.

Rotberg, R. I. 2004. "Strengthening African Leadership." Foreign Affairs, July/August. http://www.foreignaffairs.com/articles/59914/robert-i-rotberg/ strengthening-african-leadership. Accessed 1/3/2015.

Ruderman, R. S. 1995. “Leadership.” In Lipset, S. M. (Ed.). The Encyclopaedia of Democracy. Oxford: Routledge, 725-729.

Saller, R. P. 1982. Personal Patronage under the Early Empire. Cambridge: Cambridge University Press.

Sanders, J. A. 2001. "Isaiah in Luke." In Evans, C. A. \& Sanders, J. A. (Eds). Luke and Scripture: The Function of Sacred Tradition in LukeActs. Eugene: Wipf \& Stock, 14-25.

Scaer, P. J. 2005. The Lukan Passion and the Praiseworthy Death. Sheffield: Sheffield Phoenix Press.

Senaji, T. A. et al. 2014. "LEAD: Leadership Effectiveness, Motivation, and Culture in Africa: Lessons from Egypt, Ghana, Kenya, Nigeria, and Uganda." Canadian Journal of Administrative Sciences, 31: 228-244. 
Shao, J. 2001. "Alleviating Poverty in Africa." In Belshaw, D., Calderisi, R. \& Sugden, C. (Eds). Faith in Development: Partnership between the World Bank and the Churches of Africa. Oxford: Regnum, 19-30. Spencer, P. E. 2007. Rhetorical Texture and Narrative Trajectories of the Lukan Galilean Ministry Speeches: Hermeneutical Appropriation by Authorial Readers of Luke-Acts. London: T. \& T. Clark.

Tannehill, R. C. 1996. Abingdon New Testament Commentaries: Luke. Nashville: Abingdon.

Theissen, G. 1992. The Gospels in Context: Social and Political History in the Synoptic Tradition. London: T. \& T. Clark.

Tutu, D. 2003. “Foreword.” In Bloomfield, D., Barnes, T. \& Huyse, L. (Eds). Reconciliation after Violent Conflict: A Handbook. Stockholm: International Institute for Democracy and Electoral Assistance, iii. Uvin, P. 2003. “The Gacaca Tribunals in Rwanda.” In Bloomfield, D., Barnes, T. \& Huyse, L. (eds). Reconciliation after Violent Conflict: A Handbook. Stockholm: International Institute for Democracy and Electoral Assistance, 116-121. 